\title{
Spontaneous isolated coeliac artery dissection
}

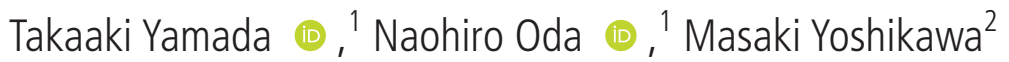

${ }^{1}$ Department of Internal Medicine, Fukuyama City Hospital, Fukuyama, Hiroshima, Japan

${ }^{2}$ Department of Cardiology, Fukuyama City Hospital, Fukuyama, Hiroshima, Japan

\section{Correspondence to} Dr Naohiro Oda; dancingqueen1212@hotmail. com

Accepted 9 February 2022

Check for updates

(c) BMJ Publishing Group Limited 2022. No commercial re-use. See rights and permissions. Published by BMJ.

To cite: Yamada T, Oda N, Yoshikawa M. BMJ Case Rep 2022;15:e249281. doi:10.1136/bcr-2022249281

\section{DESCRIPTION}

A man in his 40s who had visited a previous hospital, having sudden-onset epigastralgia, was transferred to our emergency room. Four hours before the onset of symptoms, he had eaten raw horse mackerel and salmon sushi. He had a 26 pack-year smoking history, hypertension, hyperlipidaemia and hyperuricaemia. He appeared ill, but was conscious with a blood pressure of $200 / 116 \mathrm{~mm} \mathrm{Hg}$ and heart rate of 87 beats per minute. He had severe and persistent epigastralgia accompanied with left lumbar back pain, but his abdomen with no signs of peritoneal irritation. Laboratory findings showed elevated white blood cell count $\left(12.0 \times 10^{9} / \mathrm{L}\right)$, C reactive protein $(0.65 \mathrm{mg} / \mathrm{dL})$ and creatine phosphokinase $(306 \mathrm{U} / \mathrm{L})$, but troponin I was negative, lactate $(1.4 \mathrm{mmol} / \mathrm{L})$, and $\mathrm{d}$-dimer $(0.6 \mu \mathrm{g} /$ $\mathrm{mL}$ ) levels were within normal ranges. Electrocardiography revealed no abnormalities.

Initially, gastric anisakiasis was suspected because of the typical acute severe epigastralgia, which occurred within 12 hours of ingesting raw or undercooked seafood infested with nematodes of the genus Anisakis. ${ }^{1}$ However, in this case, he had eaten sushi made with defrosted seafood, which was not a typical cause of gastric anisakiasis because parasitic anisakis is killed by freezing at $-20^{\circ} \mathrm{C}$. $^{2}$ Although there is a wide range of diseases that can cause abdominal pain in the emergency room, vascular diseases should be suspected, especially when physical examination findings are lacking in patients with acute severe abdominal pain. ${ }^{3}$ Based on these findings, we decided to perform a contrast-enhanced abdominal CT to differentiate vascular diseases. The CT showed a dissection of the coeliac artery trunk and splenic infarction (figure 1). Therefore, spontaneous isolated coeliac artery dissection (SICAD) was diagnosed. He was admitted into the high care unit and was fasted. Blood pressure-lowering therapy, analgesics, and anticoagulation were started. His abdominal pain was relieved and blood pressure was well controlled on the second day of hospitalisation, and discharged on the 18th day of hospitalisation. Ultrasonography before discharge and after 1 year showed no change in the size of the false lumen, and no aneurysm formation in the coeliac artery.

SICAD without aortic dissection is considered an extremely rare condition. With the increasing use of CT to evaluate abdominal pain, SICAD has been diagnosed more frequently. ${ }^{4}$ The maleto-female ratio of SICAD patients was 9:1 with a high age prevalence in the 50s. Approximately $40 \%$ of patients with SICAD have hypertension or a smoking history. ${ }^{4}$ The main clinical manifestation of SICAD is a sudden onset of abdominal pain, ${ }^{4}$ although some cases are asymptomatic and incidentally found on $\mathrm{CT}^{5}{ }^{5}$ Among the morphological classification of SICAD, this case was diagnosed with type IIA, intramural haematoma only. ${ }^{4}$ The coeliac

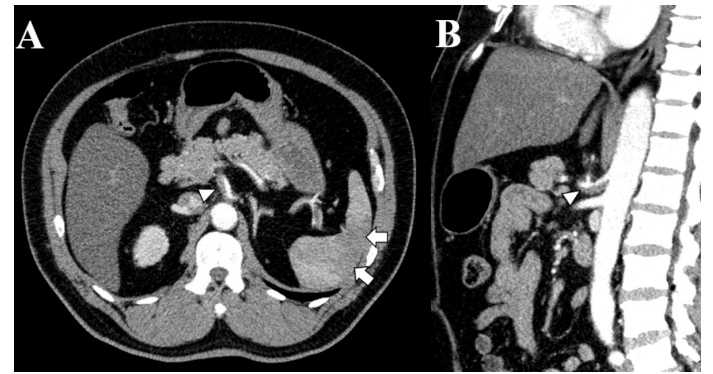

Figure 1 Contrast-enhanced abdominal and pelvic CT showed a dissection of the coeliac artery trunk (white arrow heads) and splenic infarction (white arrows) (A: axial section and B: sagittal section).

artery branches into the common hepatic artery, left gastric artery and splenic artery, and the most documented end-organ infarction associated with SICAD is splenic infarctions, which occur in $11.2 \%$ of cases. ${ }^{6}$ The gold standard for the diagnosis of SICAD is CT angiography of the abdomen. Conservative management, including fasting, blood pressure reduction and pain control, was considered to be the most common initial treatment for SICAD. Complications of severe intestinal ischaemia or ruptured aneurysms are absolute indications for endovascular treatment or surgery.

Contributors TY, NO and MY had access to the data and had contributed towards writing the manuscript.

Funding The authors have not declared a specific grant for this research from any funding agency in the public, commercial or not-for-profit sectors.

\section{Competing interests None declared.}

Patient consent for publication Consent obtained directly from patient(s)

Provenance and peer review Not commissioned; externally peer reviewed.

Case reports provide a valuable learning resource for the scientific community and can indicate areas of interest for future research. They should not be used in isolation to guide treatment choices or public health policy.

\section{Learning points}

- Spontaneous isolated coeliac artery dissection (SICAD) is a rare disease.

- SICAD is more common in middle-aged men and the main clinical manifestation is a sudden onset of abdominal pain.

- Vascular diseases should be suspected, especially when physical examination findings are lacking in patients with acute severe abdominal pain. 
Images in...

\section{ORCID iDs}

Takaaki Yamada http://orcid.org/0000-0003-4179-7098

Naohiro Oda http://orcid.org/0000-0001-8112-9233

\section{REFERENCES}

1 Shimamura Y, Muwanwella N, Chandran S, et al. Common symptoms from an uncommon infection: gastrointestinal Anisakiasis. Can J Gastroenterol Hepatol 2016;2016:1-7.
2 Adams AM, Ton MN, Wekell MM, et al. Survival of Anisakis simplex in arrowtooth flounder (Atheresthes stomia) during frozen storage. J Food Prot 2005;68:1441-6.

3 Singh M, Koyfman A, Martinez JP. Abdominal vascular catastrophes. Emerg Med Clin North Am 2016:34:327-39.

4 Kim SR, Park TK, Choi S-H, et al. Natural history of spontaneous isolated celiac artery dissection after conservative treatment. J Vasc Surg 2018:68:55-63.

5 DiMusto PD, Oberdoerster MM, Criado E. Isolated celiac artery dissection. J Vasc Surg 2015;61:972-6.

6 Acosta S, Gonçalves FB. Management of spontaneous isolated mesenteric artery dissection: a systematic review. Scand J Surg 2021;110:130-8.

Copyright 2022 BMJ Publishing Group. All rights reserved. For permission to reuse any of this content visit https://www.bmj.com/company/products-services/rights-and-licensing/permissions/

BMJ Case Report Fellows may re-use this article for personal use and teaching without any further permission.

Become a Fellow of BMJ Case Reports today and you can:

- Submit as many cases as you like

- Enjoy fast sympathetic peer review and rapid publication of accepted articles

- Access all the published articles

- Re-use any of the published material for personal use and teaching without further permission

\section{Customer Service}

If you have any further queries about your subscription, please contact our customer services team on +44 (0) 2071111105 or via email at support@bmj.com.

Visit casereports.bmj.com for more articles like this and to become a Fellow 